\title{
Morphological and Mitochondrial DNA Analyses of Oysters in the Northern Bay of Bengal, Bangladesh
}

\author{
Mohammed S. N. Chowdhury \\ Kimberly S. Reece \\ Virginia Institute of Marine Science \\ Sourav S. Joy \\ Loren D. Coen \\ Aad C. Smaal
}

Follow this and additional works at: https://scholarworks.wm.edu/vimsarticles

Part of the Aquaculture and Fisheries Commons

\section{Recommended Citation}

Chowdhury, Mohammed S. N.; Reece, Kimberly S.; Joy, Sourav S.; Coen, Loren D.; and Smaal, Aad C., Morphological and Mitochondrial DNA Analyses of Oysters in the Northern Bay of Bengal, Bangladesh (2021). Journal of Shellfish Research, 40(2), 213-229.

doi: $10.2983 / 035.040 .0203$

This Article is brought to you for free and open access by the Virginia Institute of Marine Science at W\&M ScholarWorks. It has been accepted for inclusion in VIMS Articles by an authorized administrator of W\&M ScholarWorks. For more information, please contact scholarworks@wm.edu. 


\title{
MORPHOLOGICAL AND MITOCHONDRIAL DNA ANALYSES OF OYSTERS IN THE NORTHERN BAY OF BENGAL, BANGLADESH
}

\author{
MOHAMMED S. N. CHOWDHURY, ${ }^{1 *}$ KIMBERLY S. REECE, ${ }^{2}$ SOURAV S. JOY, ${ }^{3}$ \\ LOREN D. COEN ${ }^{4}$ AND AAD C. SMAAL ${ }^{5,6}$ \\ ${ }^{1}$ Institute of Marine Sciences, University of Chittagong, Chittagong 4331, Bangladesh; ${ }^{2}$ Virginia Institute \\ of Marine Science, William \& Mary, PO Box 1346, Gloucester Point, VA 23062; ${ }^{3}$ Department of \\ Fisheries, University of Chittagong, Chittagong 4331, Bangladesh; ${ }^{4}$ Department of Biological Sciences \\ and Harbor Branch Oceanographic Institute (HBOI), Florida Atlantic University, clo 16007 Waterleaf \\ Lane, Ft. Myers, FL 33908; ${ }^{5}$ Wageningen Marine Research, Wageningen University and Research, PO \\ Box 77, 4400 AB Yerseke, The Netherlands; ${ }^{6}$ Aquaculture and Fisheries Group, Wageningen University \\ and Research, PO Box 338, 6700 AH Wageningen, The Netherlands
}

\begin{abstract}
The geographic boundaries of many important habitat-building shallow estuarine oyster (Family Ostreidae) species are poorly understood, especially in subtropical and tropical waters. These keystone species often have extensive historical and extant ranges, in part because of their ability to adapt to diverse environmental conditions and the transfer and introduction of a few species worldwide for aquaculture production. In addition, oysters exhibit morphological plasticity additionally confounding species identification and taxonomy. Molecular techniques have led to significant improvements in oyster systematics and taxonomy but have not been applied to oysters from many tropical regions, including the coastal areas of the Indian Ocean such as Bangladesh. Because species' identification based on morphological traits alone, in this case primarily shell characteristics, were inadequate, phylogenetic analyses of mitochondrial cytochrome oxidase subunit I gene fragments was also done to confirm the identity of oyster specimens collected from Bangladesh coastal waters. Phylogenetic analyses of collected oyster samples confirmed the two monophyletic subclades of the Ostreidae family Crassostrea and Saccostrea, and five oyster lineages from the region of Bangladesh were identified: Crassostrea gryphoides, Crassostrea belcheri, Saccostrea cuccullata lineage B, S. cuccullata lineage F, and Saccostrea mordax. A new addition to the list of Crassostrea species, C. belcheri was found in Bangladesh, but C. belcheri, C. gryphoides, and S. cuccullata are considered "common" species in the neighboring states of India and Myanmar indicating a widespread distribution of these species along the entire coast of the Bay of Bengal. However, S. mordax, is a new record for the Bay of Bengal region including the coastal waters of Andaman and Nicobar Islands, and thus extends the geographical distribution of this species.
\end{abstract}

KEY WORDS: Bay of Bengal, shell plasticity, morphology, cytochrome oxidase subunit I (COI), Saccostrea mordax

\section{INTRODUCTION}

Oysters (Family Ostreidae) are considered keystone species and commonly referred to as "ecosystem engineers" for their ability to exert a large influence on the ecosystem function in coastal waters (Jones et al. 1994, 1997, Grabowski \& Peterson 2007, Arkema et al. 2013, Coen \& Grizzle 2016, Bayne 2017). Cultured oysters provide similar services where deployed (e.g., Dumbauld et al. 2009). Global annual production amounted to approximately 18 million metric tons in 2018, almost entirely coming from aquaculture (FAO 2018). A large number of coastal inhabitants rely on aquaculture, and processing of oyster meats and shell products in many countries for their livelihood, particularly in Asia (e.g., Trivedi et al. 2014, Krause et al. 2019).

Globally, some populations of some oyster species are declining at an alarming rate, and some have reached near extinction as a result of overfishing, habitat destruction, pollution, and native and introduced diseases (see Carranza et al. 2009, Beck et al. 2011, zu Ermgassen et al. 2012). Restoration and conservation of oyster species and their habitats are increasingly promoted as a way to protect and enhance the biodiversity of local waters (Beck et al. 2011, Fitzsimons et al. 2019). Without

*Corresponding author. E-mail: msnchowdhury@cu.ac.bd DOI: $10.2983 / 035.040 .0203$ knowing which oyster species one is dealing with, as well as their population genetics, it is difficult to impossible to formulate management strategies that will ensure sustainable use of oyster resources.

Because of taxonomic confusion and inadequate surveys, the natural geographic ranges of many species are not well understood (Lohan et al. 2015, Guo et al. 2018). High plasticity in shell morphology, along with widespread geographic distributions has led to many errors, and significant confusion with the identification of oyster species (Lam \& Morton 2006, Liu et al. 2011, Leray \& Knowlton 2015, Lohan et al. 2015). Shell morphology can be influenced by many environmental factors (Tack et al. 1992, Wilk \& Bieler 2009), making shell characteristics difficult to define and use for species identification based on these external characters alone (Lohan et al. 2015). More than 100 extant oyster species have been recognized currently by various authors (Guo et al. 2018), whereas Harry (1985) recognized only 36 valid species, whereas others have reported that in some instances the same species name has been applied to different ecotypes, morphotypes, or shell forms (Harry 1985, Lam \& Morton 2006). A recent review by Guo et al. (2018) found 99 species or lineages of living oysters, but not all have been genetically confirmed, or for that matter adequately characterized due to limited DNA sequence data. Current molecular techniques, including DNA sequencing, can resolve some 
of the difficulties with oyster species' classification and lead to significant improvements in oyster taxonomy.

In the last two decades, the analyses of DNA sequence data have provided suitable molecular tools for (1) species identification (Cordes et al. 2008, Reece et al. 2008, Salvi et al. 2014, Xia et al. 2014, Lohan et al. 2015, Li et al. 2017); (2) distinguishing among various species of the same genus (Banks et al. 1993, O'Foighil et al. 1995, Boudry et al. 1998, Klinbunga et al. 2000, Klinbunga et al. 2001, Klinbunga et al. 2003, Lam \& Morton 2006, Cordes et al. 2008, Wang et al. 2010, Sekino \& Yamashita 2013, Hsiao et al. 2016); (3) determining the origin of introductions (O'Foighil et al. 1998, Wang et al. 2010); (4) verifying a species' presence in a geographic area (Hedgecock et al. 1999, Varela et al. 2007, Galvão et al. 2013, Trivedi et al. 2014, Galvão et al. 2017); (5) characterizing a new species (Boudry et al. 2003, Lam \& Morton 2003, 2004, Wang et al. 2004, Xia et al. 2014); and finally (6) distinguishing between hatchery and wild stocks (Milbury et al. 2004, Zhang et al. 2005). Nevertheless, molecular classification, and identification have not been applied to oysters in many regions of the world ( $\mathrm{Li}$ et al. 2017). The focus of this study is the oysters from the northern Bay of Bengal region, which have been poorly studied to date.

The Bay of Bengal lies in the far northeast region of the Indian Ocean, bounded on the west and northwest by the Indian coast, on the north by the coast of Bangladesh, and on the east by the coast of Myanmar and the Indian Islands of Andaman and Nicobar. The Bay's southern limit is a line between Sri Lanka, and the north-westernmost point of Sumatra (Indonesia) (see Fig. 1). Past molecular analyses confirmed the presence of nine oyster species along the eastern Indian coast (Trivedi et al. 2014), three from the coast of Myanmar (Li et al. 2017), and two along the Sri Lankan coast (Amarakoon 2016, Wanninayake 2017). An encyclopedia of flora and fauna for Bangladesh reported a total of seven oyster species in its coastal waters: Crassostrea ariakensis, Crassostrea gigas, Crassostrea gryphoides, Crassostrea nippona; Crassostrea virginica, and Saccostrea cuccullata (Siddique et al. 2007). To date, there has been no molecular validation of these seven morphospecies' identifications. Here, we aim to confirm the identification of various oyster specimens collected along the coast of Bangladesh through morphological and molecular characterizations, along with phylogenetic analyses based on the mitochondrial cytochrome oxidase subunit I (COI) gene applied to our collections.

\section{MATERIALS AND METHODS}

\section{Sample Collection}

Oyster samples were collected from the wild populations at five different locations (Kutubdia, Moheshkhali, Inani, Teknaf, and Saint Martin's Island) as shown in Figure 1. Most of the oysters were collected from intertidal habitats at low tide, except from offshore Saint Martin's Island where they were collected from the subtidal zone by SCUBA diving. The bottom characteristics of these habitats varied widely: (1) muddy bottoms (Kutubdia and Teknaf); (2) mangrove vegetated area (Moheshkhali); and (3) rocky boulders (Inani, Saint Martin's Island). Moreover, the salinity showed seasonal variations ranging from 10 to $37 \mathrm{ppt}$ among those sites, whereas the tidal range varied from 3 to $5 \mathrm{~m}$. After sampling, we placed the oysters in coolers on ice and returned them to the laboratory, where they were kept at approximately $4^{\circ} \mathrm{C}$ for not more than $72 \mathrm{~h}$ before processing. Prior to any measurement and tissue sampling, we removed epibionts and mud from the shells. Oysters were tentatively identified using the morphological characters of the shell described in published materials (e.g., Ahmed \& Islam 1978, Romashko 1992, Littlewood 1994, Tucker Abbott \& Morris 1995, Lam \& Morton 2003, 2004, 2006, Wang et al. 2004, Siddique et al. 2007, Hossain et al. 2014, Ahmed 2016). The shell characters measured and observed were (1) general size; (2) shape and surface sculpture; (3) hinge line and ligament position and extent; (4) attachment area of the left valve; (5) presence and pattern of chomata; (6) position, color, and relative size of the adductor muscle scar; and (7) external and internal shell color. For molecular analyses, the whole soft body of the oysters was dislodged from the shells and fixed in $95 \%$ ethanol.

\section{DNA Extraction and Polymerase Chain Reaction Amplification}

For species diagnosis, the $C O I$ gene was selected as the molecular marker. Total genomic DNA was extracted from macerated tissue $(>20 \mathrm{mg}$ ) using a commercial DNA isolation kit following the manufacturer's protocol (Qiagen Inc., Santa Clara, CA). The LCO1490 (forward primer, 5'-GGT CAA CAA ATC ATA AAG ATA TTG G-3') and HCO-2198 (reverse primer, 5'-TAA ACT TCA GGG TGA CCA AAA AAT CA-3') primer set was used to amplify the COI gene fragment (Folmer et al. 1994) as described in Cordes et al. (2008).

\section{DNA Sequencing and Analysis}

Amplified fragments of the $C O I$ gene were purified with a QIAquick polymerase chain reaction (PCR) purification kit (Qiagen) cloned with the TOPO TA cloning kit for sequencing (ThermoFisher Scientific) according to the manufacturer's protocol. Plasmids were screened for inserts and inserts were sequenced as previously described (Reece et al. 2017) and reactions were run on an Applied Biosystems 3700XL automated sequencer. All sequences were verified by Codon-Code Aligner v3.7.1.1 (CodonCode Corporation), then analyzed by the basic local alignment search tool (BLAST) online (http://blast.ncbi. nlm.nih.gov/Blast.cgi).

Cytochrome oxidase subunit I gene fragment amplicons from 15 individual oysters representing five nominal species/ lineages were sequenced for this study (Table 1). An additional 84 oyster $C O I$ gene sequences from GenBank representing 17 species; 12 Crassostrea, six Saccostrea, and two Ostrea (Table 2) with two lineages of Saccostrea cuccullata and three lineages of Saccostrea mordax were included in the phylogenetic analysis. Sequences were aligned using the Muscle algorithm in MacVector v.15.5.3 (Pro Edition, MacVector Inc., Apex, NC) using the default parameters. The alignment file of the sequences was trimmed to 638 positions for parsimony analysis (MP) and 467 for neighbor joining (NJ) and maximum likelihood (ML) analyses to account for the shortest sequence to allow inclusion of published sequences from more species. Parsimony analysis, ML, and NJ analyses were done using PAUP* 4.0 build 168 (Swofford 2002) with the Ostrea species COI sequences, Ostrea 

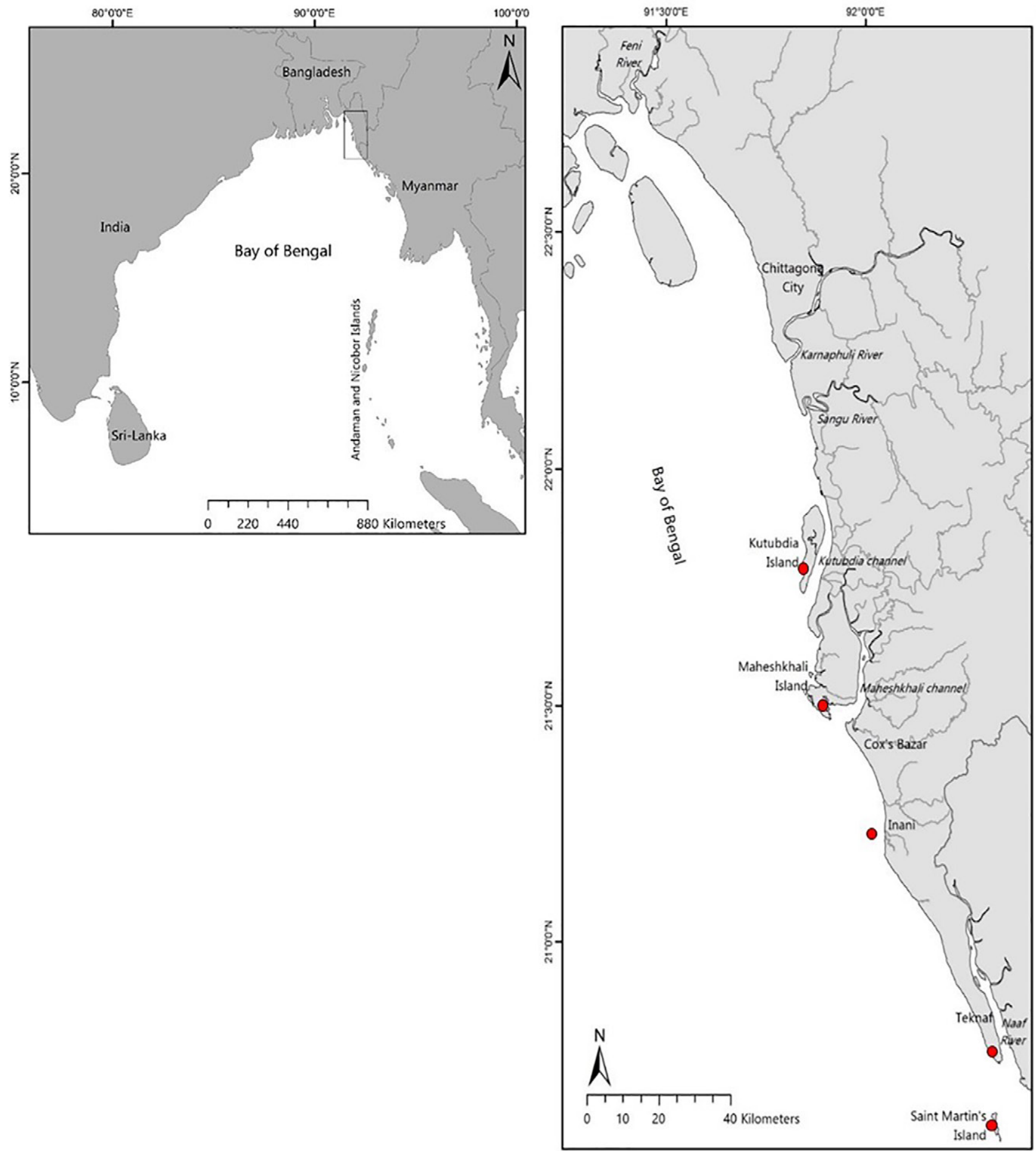

Figure 1. A map showing the collection sites along the southeast coast of Bangladesh: (1) Kutubdia Island; (2) Moheshkhali Island; (3) Inani; (4) Teknaf; and (5) Saint Martin's Island, where oyster samples were collected for morphological and molecular analysis.

lurida and Ostrea edulis, used as the outgroup. Neighbor joining analysis was done based on Kimura two-parameter (K2P) distances. A heuristic MP analysis was limited to 10,000 equally parsimonious trees. MP bootstrap (BS) analysis was done with 1,000 random additions of 1,000 replicates with the maximum number of trees saved at each replicate set at 500 . The model for
ML was determined using the AICc criteria with the automated model selection based on 11 parameters in PAUP. Maximum likelihood BS analysis was done with 100 replicates. The oyster lineages were determined based on Lam and Morton (2006), Xia and Yu's unpublished COI sequences and Sekino and Yamashita (2013). 
TABLE 1.

Sample abbreviations, collection sites, dates, and source, along with the species identifications for the samples as suggested by the BLAST and molecular phylogenetic analyses of the COI sequences.

\begin{tabular}{|c|c|c|c|c|c|c|}
\hline SL & $\begin{array}{c}\text { Sample } \\
\text { abbreviation } \\
\text { GenBank\# } \\
\end{array}$ & Sample collection site & Collection date & BLAST result & $\begin{array}{c}\text { Nucleotide identity from } \\
\text { BLAST alignment } \\
\text { (GenBank sequences) }\end{array}$ & $\begin{array}{c}\text { Clade affiliation in COI } \\
\text { phylogenetic analyses } \\
\text { (lineage*) }\end{array}$ \\
\hline 1 & $\begin{array}{l}\text { CbK1 } \\
\text { MZ686551 }\end{array}$ & Kutubdia Island & $22 / 11 / 2016$ & $\begin{array}{l}\text { Crassostrea belcheri, } \\
\text { Crassostrea nippona }\end{array}$ & $\begin{array}{l}596 / 597(99.8 \%) \\
(\text { EU007466, MN119652) }\end{array}$ & C. belcheri \\
\hline 2 & $\begin{array}{l}\text { ScFK2 } \\
\text { MZ686560 }\end{array}$ & Kutubdia Island & $22 / 11 / 2016$ & $\begin{array}{l}\text { Saccostrea cuccul- } \\
\text { lata, Saccostrea } \\
\text { malabonensis }\end{array}$ & $\begin{array}{l}592 / 593(99.8 \%) \\
\text { (MF198445, KU947216, } \\
\text { KU947215, LC005431) }\end{array}$ & S. cuccullata (lineage F) \\
\hline 3 & $\begin{array}{l}\text { CbK3 } \\
\text { MZ686552 }\end{array}$ & Kutubdia Island & $15 / 11 / 2016$ & C. belcheri & $\begin{array}{l}597 / 597(100 \%) \\
(\text { EU007472, AY160755) }\end{array}$ & C. belcheri \\
\hline 4 & $\begin{array}{l}\text { ScFK4 } \\
\text { MZ686561 }\end{array}$ & Kutubdia Island & $15 / 11 / 2016$ & $\begin{array}{l}\text { S. cuccullata, } \\
\text { S. malabonensis }\end{array}$ & $\begin{array}{l}592 / 593(99.8 \%) \\
\text { (MF198445, KU947216, } \\
\text { KU947215, LC005431) }\end{array}$ & S. cuccullata (lineage F) \\
\hline 5 & $\begin{array}{l}\text { ScBK5 } \\
\text { MZ686555 }\end{array}$ & Kutubdia Island & $15 / 11 / 2016$ & S. cuccullata & $\begin{array}{l}592 / 597(99.2 \%) \\
(\mathrm{KU} 947197)\end{array}$ & S. cuccullata (lineage B) \\
\hline 6 & $\begin{array}{l}\text { ScBK6 } \\
\text { MZ686556 }\end{array}$ & Kutubdia Island & $15 / 11 / 2016$ & $\begin{array}{l}\text { S. cuccullata, } \\
\text { Saccostrea kegaki, } \\
\text { Saccostrea echinata, } \\
\text { Saccostrea } \\
\text { glomerata }\end{array}$ & $\begin{array}{l}590 / 597(98.8 \%) \\
\text { (KU947212, KT936590, } \\
\text { KU310915, KU310917) }\end{array}$ & S. cuullata (lineage B) \\
\hline 7 & $\begin{array}{l}\text { ScBK7 } \\
\text { MZ686557 }\end{array}$ & Kutubdia Island & $15 / 11 / 2016$ & S. cuccullata & $\begin{array}{l}594 / 597(99.5 \%) \\
\text { (KT992045, КT992044) }\end{array}$ & S. cuccullata (lineage B) \\
\hline 8 & $\begin{array}{l}\text { ScFI1 } \\
\text { MZ686558 }\end{array}$ & Inani & $15 / 11 / 2016$ & $\begin{array}{l}\text { S. cuccullata, } \\
\text { S. malabonensi }\end{array}$ & $\begin{array}{l}588 / 592(99.3 \%) \\
(\text { KX961673) } \\
585 / 593(98.7 \%) \\
(M F 198445, \text { KU947215, } \\
\text { KU947216, LC005431) }\end{array}$ & S. cuccullata (lineage F) \\
\hline 9 & $\begin{array}{l}\text { ScFI2 } \\
\text { MZ686559 }\end{array}$ & Inani & $15 / 11 / 2016$ & $\begin{array}{l}\text { S. cuccullata, } \\
\text { S. malabonensi }\end{array}$ & $\begin{array}{l}537 / 545(98.5 \%) \\
\text { (MF198445, KU947216, } \\
\text { KU947215, LC005431) }\end{array}$ & S. cccullata (lineage F) \\
\hline 10 & $\begin{array}{l}\text { ScFT1 } \\
\text { MZ686562 }\end{array}$ & Teknaf & $16 / 11 / 2016$ & $\begin{array}{l}\text { S. cuccullata, } \\
\text { S. malabonensi }\end{array}$ & $\begin{array}{l}591 / 593(99.7 \%) \\
\text { (MF198445, KU947216, } \\
\text { KU947215, LC005431) }\end{array}$ & S. cuccullata (lineage F) \\
\hline 11 & $\begin{array}{l}\text { CgM1 } \\
\text { MZ686554 }\end{array}$ & Moheshkhali Island & $22 / 11 / 2016$ & $\begin{array}{l}\text { Crassostrea } \\
\text { gryphoides }\end{array}$ & $\begin{array}{l}579 / 581(99.7 \%) \\
(\mathrm{KX} 961667) \\
583 / 599(97 \%) \\
(\text { EU007488) }\end{array}$ & C. gryphoides \\
\hline 12 & $\begin{array}{l}\mathrm{CbS1} \\
\mathrm{MZ} 686553\end{array}$ & St. Martin's Island & $16 / 01 / 2017$ & C. belcheri & $\begin{array}{l}536 / 540(99.3 \%) \\
\text { (GU591448) }\end{array}$ & C. belcheri \\
\hline 13 & $\begin{array}{l}\text { SkBS2 } \\
\text { MZ686563 }\end{array}$ & St. Martin's Island & $17 / 01 / 2017$ & S. cuccullata & $\begin{array}{l}597 / 597(100 \%) \\
(\text { KT992045, KT992044) }\end{array}$ & S. cuccullata (lineage B) \\
\hline 14 & $\begin{array}{l}\text { SmAS3 } \\
\text { MZ686564 }\end{array}$ & St. Martin's Island & $17 / 01 / 2017$ & S. $\operatorname{mordax}$ & $\begin{array}{l}590 / 593(99.5 \%) \\
(\mathrm{HQ} 661025)\end{array}$ & S. mordax (lineage A) \\
\hline 15 & $\begin{array}{l}\text { SmAS4 } \\
\text { MZ686565 }\end{array}$ & St. Martin's Island & $17 / 01 / 2017$ & S. $\operatorname{mordax}$ & $\begin{array}{l}590 / 593(99.5 \%) \\
(\mathrm{HQ661025)}\end{array}$ & S. mordax (lineage A) \\
\hline
\end{tabular}

BLAST, basic local alignment search tool; COI, cytochrome oxidase subunit I.

* Lineage IDs are based on Lam and Morton (2006) and derived from affiliation with COI sequences from Xia and Yu (personal communication) and Sekino and Yamashita (2013). 
TABLE 2.

GenBank accession numbers of sequences from previous studies included in the phylogenetic analyses.

\begin{tabular}{|c|c|c|c|c|c|}
\hline $\begin{array}{c}\text { GenBank } \\
\text { accession \# }\end{array}$ & Species & $\begin{array}{l}\text { Collection } \\
\text { location }\end{array}$ & $\begin{array}{c}\text { GenBank } \\
\text { accession \# }\end{array}$ & Species & Collection location \\
\hline EU007501 & Crassostrea ariakensis & China & AF120651 & Ostrea edulis & United States \\
\hline EU007505 & C. ariakensis & Japan & KU947197 & Saccostrea cuccullata & China \\
\hline EU007506 & C. ariakensis & United States & KU947212 & S. cuccullata & China \\
\hline AY160755 & Crassostrea belcheri & Hong Kong & KT992044 & S. cuccullata & China \\
\hline EU007466 & C. belcheri & Thailand & KT992045 & S. cuccullata & China \\
\hline EU007472 & C. belcheri & Malaysia & MF198444 & S. cuccullata & Malaysia \\
\hline EU007473 & C. belcheri & Malaysia & MF198445 & S. cuccullata & Malaysia \\
\hline GU591440 & C. belcheri & Malaysia & EU816089 & S. cuccullata & China \\
\hline GU591451 & C. belcheri & Malaysia & КР967577 & S. cuccullata & China \\
\hline KX961668 & C. belcheri & Myanmar & KT149315 & S. cuccullata & French Polynesia \\
\hline KX961669 & C. belcheri & Myanmar & FJ262984 & S. cuccullata & India \\
\hline FJ717611 & Crassostrea gasar & Brazil & KU947218 & S. cuccullata & China \\
\hline HМ003518 & C. gasar & Brazil & EU816077 & S. cuccullata & China \\
\hline HM003523 & C. gasar & Brazil & AB748834 & S. cuccullata & Japan \\
\hline EU007507 & C. gigas & China & EU816086 & S. cuccullata & China \\
\hline EU007508 & C. gigas & Japan & AB721961 & S. cuccullata & Japan \\
\hline EU007511 & C. gigas & United States & AY038076 & S. cuccullata & Thailand \\
\hline EU007488 & Crassostrea gryphoides & India & KU947215 & S. cuccullata & China \\
\hline EU007492 & C. gryphoides & India & KU947216 & S. cuccullata & China \\
\hline KX961667 & C. gryphoides & Myanmar & KU947217 & S. cuccullata & China \\
\hline EU007452 & Crassostrea hongkongensis & China & EU816094 & S. cuccullata & China \\
\hline EU007454 & C. hongkongensis & China & KU310915 & Saccostrea echinata & China \\
\hline EU007456 & C. hongkongensis & China & EU007482 & Saccostrea glomerata & Australia \\
\hline AY038078 & $\begin{array}{l}\text { Crassostrea bilineata } \\
\text { (syn. iredalei) }\end{array}$ & Thailand & EU007483 & S. glomerata & Australia \\
\hline EU007464 & C. bilineata & Thailand & JQ027294 & Saccostrea kegaki & Taiwan \\
\hline JF915448 & C. bilineata & Malaysia & KP067909 & S. kegaki & Korea \\
\hline JF915472 & C. bilineata & Malaysia & КР067910 & S. kegaki & Korea \\
\hline EU007460 & Crassostrea madrasensis & India & KT936590 & S. kegaki & China \\
\hline FJ948069 & C. madrasensis & Malaysia & LC005431 & Saccostrea malabonensis & Japan \\
\hline JF915457 & C. madrasensis & Malaysia & KX961672 & S. malabonensis & Myanmar \\
\hline JF915507 & C. madrasensis & Malaysia & KX961673 & S. malabonensis & Myanmar \\
\hline MN119652 & Crassostrea nippona & Myanmar & EU816064 & Saccostrea mordax & China \\
\hline FJ717639 & Crassostrea rhizophorae & Brazil & EU816066 & S. mordax & China \\
\hline НМ003496 & C. rhizophorae & Brazil & EU816069 & S. $\operatorname{mordax}$ & China \\
\hline KP455050 & C. rhizophorae & Panama & KU310917 & S. glomerata & China \\
\hline EU007479 & Crassostrea sikamea & China & EU816071 & S. $\operatorname{mordax}$ & China \\
\hline EU007476 & C. sikamea & United States & EU816075 & $\begin{array}{l}\text { S. mordax, } \\
\text { Saccostrea mordoides }\end{array}$ & China \\
\hline EU007480 & C. sikamea & China & EU816076 & S. mordax, S. mordoides & China \\
\hline AF152566 & Crassostrea virginica & United States & HQ661025 & S. $\operatorname{mordax}$ & China \\
\hline EU007485 & C. virginica & United States & KP455047 & Saccostrea palmula & Panama (Pacific) \\
\hline FJ743529 & C. virginica & United States & KP455056 & S. palmula & Panama (Pacific) \\
\hline KT317529 & Ostrea lurida & Canada & KP455058 & S. palmula & Panama (Pacific) \\
\hline
\end{tabular}


RESULTS

Taxonomic Analysis

Based on shell (morphological) characteristics, four Ostreidae species were separated from the overall specimens collected as individual species falling under two distinct genera. All of the analyzed specimens (see Fig. 2) were deposited in the Marine Biology Museum, University of Chittagong. Taxonomic descriptions of identified oysters are given below.

Suborder Ostreina Férussac, 1822

Superfamily Ostreoidea Rafinesque, 1815

Family Ostreidae Rafinesque, 1815

Subfamily Crassostreinae Torigoe, 1981
Genus Crassostrea Sacco, 1897

Crassostrea belcheri (Sowerby 1871)

Crassostrea gryphoides (von Schlotheim 1820)

Genus Saccostrea (Dolfuss \& Dautzenberg 1920)

Saccostrea cuccullata (Born 1778)

Saccostrea mordax (Gould 1850)

Crassostrea sacco, 1897

(See Fig. 2A-F)

Crassostrea (Sacco 1897; Dall 1889; Hirase 1930,

Stenzel 1971, Torigoe 1981, Harry 1985, Coan et al. 2000)

Dioeciostrea (Orton 1928)

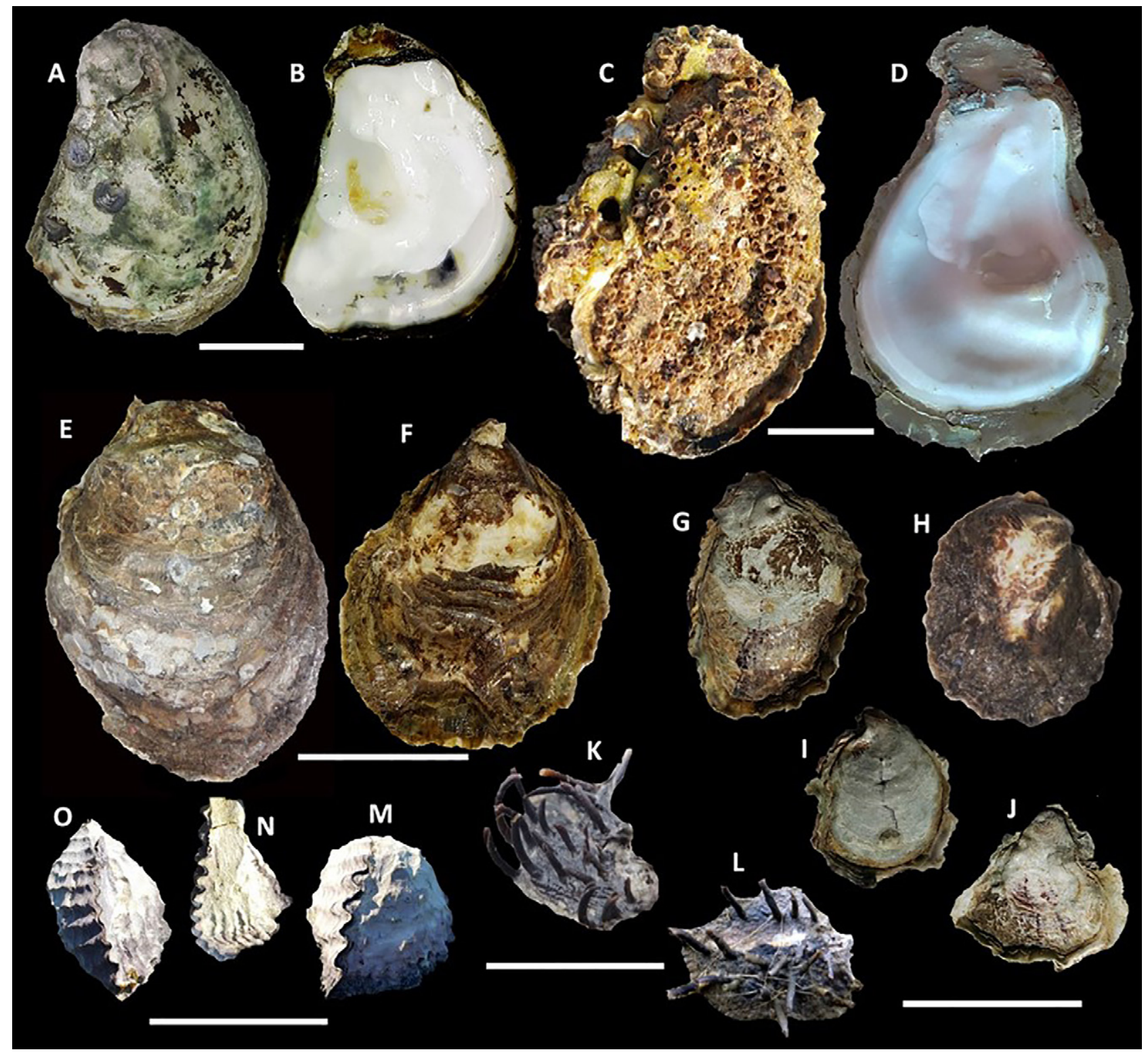

Figure 2. Crassostrea and Saccostrea from the coastal waters of Bangladesh showing different external and internal views of the different valves. (A-D) Crassostrea belcheri. (E, F) Caccostrea gryphoides. (G-I) Saccostrea cuccullata (lineage F). (J-L) S. cuccullata (lineage B). (M-O) Saccostrea mordax. Scale bar $=\mathbf{5 0} \mathbf{~ m m}$. 


\section{Description}

Size varies among the species, reaching up to $210 \mathrm{~cm}$ in shell height (SH). Outline is variable among the available individuals, but is usually long and rounded to ovate to elongate orbicular. The external side of the shell is rough. The scales on the shell surface are irregularly spaced with squamae growing on the surface. They are either simple or frilled along their free marginal ends. The right valve is cup-shaped, with a subumbonal space in some individuals. Promyal chambers are common. The left valve shows a well-developed umbonal cavity. Chomata are absent. The adductor muscle scar is situated to the postero-ventral valve margin. The hinge does not have teeth, and the ligament is partly external and nonincubatory.

Crassostrea belcheri (Sowerby 1871)

(Fig. 2A-D)

Ostrea discoidea (Rai 1933)

Ostrea belcheri (Awati \& Rai 1931, Kazmi 1953, Hasan 1960)

Crassostrea belcheri (Patel \& Jetani 1991a, Patel \& Jetani 1991b, Chen 1972, Kong \& Luh 1977).

\section{Material Examined}

IMSCU/I1611.1, one specimen of $140 \mathrm{~mm} \mathrm{SH}$; Moheshkhali Island collected at $1 \mathrm{~m}$ depth during low tide; November 2016; and IMSCU/I1701.1; one specimen of $210 \mathrm{~mm} \mathrm{SH}$; St. Martin's Island, collected at $2 \mathrm{~m}$ depth during low tide; January 2017.

\section{Description}

Shell large to very large in size (140-210 mm SH), and variable in shape, but generally long and rounded to ovate to elongate orbicular in outline (Fig. 2A, D), with shell foliaceous, thick (40-75 mm), external surface quite lamellose. Both valves are convex, and the left or lower valve is heavy and more convex than the right or upper valve, with a small- to large-sized attachment area. A shallow umbonal cavity presents under the broad hinge of the left valve (see Fig. 2B). Ligament is brown in color, whereas the adductor muscle scar is white and large, oblong lunate, or crescent shaped, somewhat concave antero-dorsally, and roughly as far from the ventral margin as from the hinge. Exterior coloration is dull green, and the interior is chalky white and sometimes nacreous with no denticulations on margins (Fig. 2A, B). Chomata are completely absent (Fig. 2B). A promyal chamber is present (see Fig. 2B, D). The commissural shelf is narrow (Fig. 2C, D). Anterior end of the shell is rather narrow compared with the posterior side and the ventral margin is slightly expanded.

\section{Distribution}

This species was found on jetty pilings in Kutubdia and Saint Martin's Islands, which have two completely different ecosystems (i.e., brackish and marine water, respectively). It indicates that this species is euryhaline in nature tolerating a salinity range from 10 to $37 \mathrm{ppt}$, growing in both sheltered (i.e., $0.10-0.50 \mathrm{~m}$ wave heights), and exposed environments (i.e., $0.5-$ $2.50 \mathrm{~m}$ wave heights).

\section{Remarks}

This is a newly recorded oyster species for the coastal waters of Bangladesh.
Crassostrea gryphoides (von Schlotheim 1820)

(Fig. 2E-F)

Ostrea gryphoides (Awati \& Rai 1931, Kazmi 1953, Hasan 1960, Vredenburg 1904, Durve 1967)

Crassostrea gryphoides (Durve 1974, Patel \& Jetani 1991a, Patel \& Jetani 1991b, Ahmed 1971, Rao 1974)

Crassostrea rivularis (Asif 1975)

Crassostrea cattukensis (Nagabhushanam \& Mane 1991)

\section{Material Examined}

IMSCU/I1611.1 three specimen of 93-110 mm SH; Moheshkhali Island at >2 m depth; November 2016.

\section{Description}

Shell elongated, asymmetrical, and jointed at the hinge by a ligament; anterior region is narrow, whereas posterior region is broad; inequivalve, height is much greater than length. Outline is variable, usually straight or slightly curved (Fig. 2E, F). Shell becomes gradually broader toward the ventral margin. Left or lower valve is slightly concave, heavy, and thick and larger than the right valve, and deeply recessed beneath the hinge area (Fig. 2E). Right or upper valve is operculiform, flat and less thick, forming a lid over the lower valve and scaly at the margin (see Fig. $2 F$ ). Surface of the right valve is not smooth, with lamellar irregularly protruding with obvious concentric growth marks. Growth and lengthy cylindrical ligament area observed on the right valve. Nearly wide length resilifer. Hinge area is elongate, with a groove curving to the left or right valve. Umbonal cavity is well-developed, and recurved on the left valve. Promyal chamber presents on right side. Interior coloration is whitish and shiny, with irregular chalky white patches. Chomata are completely absent from the internal margin of both valves. The commissural shelf is narrow. Attachment area is small to medium in size. Adductor muscle scar is white, reniform, or crescent shaped, and nearly straight dorsally, and close to posterodorsal margin. Nonincubatory.

\section{Distribution}

This species occurs in the sandy intertidal, and subtidal (approximately $2 \mathrm{~m}$ depth) bottoms of creeks, estuaries, and channels in the Moheshkhali region (south eastern coast) of Sonadia Island, Moheshkhali.

\section{Remarks}

The species was previously recorded from the Sundarban (south-west coast) areas of Bangladesh (Siddique et. al. 2007). This study adds a new locality (i.e., Sonadia Island, Moheshkhali) from the south eastern coastal region, extending the geographic distribution from the east to the west coast of Bangladesh (see Fig. 1).

\section{Saccostrea (Dolfuss \& Dautzenberg 1920)}

(Fig. 2G-O)

Saccostrea (Dollfus \& Dautzenberg 1920, Stenzel 1971, Torigoe 1981, Harry 1985).

\section{Description}

Small- to medium-sized. Right or upper valve operculiform and large, slender conical to cornucopia-like. Left or lower valve carrying very high, slender ligamental area, with a large attachment area carrying many rough, imbricating growth scales with 
rough irregular rounded radial folds extending into small protruding lobes. Comparatively deep umbonal cavity is present. Nevertheless, the size of the umbonal cavity varied among individuals, depending on the attachment area of left valve. Interior with obvious adductor muscle scar. Chomata present all around the internal shell margins, but faded ventrally or encircling the entire valve. Presence of promyal chamber on the right side. Nonincubatory in nature.

Saccostrea cuccullata (Born 1778)

(Fig. 2G-L)

Ostrea cornucopiae (Chemnitz 1785)

Ostrea forskaelii (Chemnitz 1785)

Ostrea forskali (Gmelin 1791)

Ostrea tuberculata (Lamarck 1819)

Ostrea cornucopiaeformis (Saville-Kent 1893);

Ostrea cuccullata (Lamarck 1819, Hornell 1918, Awati \&

Rai 1931, Kazmi 1953, Ranjah 1960)

Crassostrea tuberculata (Ahmed 1971, Thompson et al.

1954, Carreon 1969)

Crassostrea cuccullata (Ranson 1960, Patel \& Jetani

1991a, Patel \& Jetani 1991b)

Saccostrea cuccullata (Stenzel 1971, Ahmed 1975, Morris 1985, Rao 1987, Lam \& Morton 2003, do Amaral \&

Simone 2016)

\section{Material Examined}

IMSCU/I1611.4, three specimens of $30-57 \mathrm{~mm} \mathrm{SH}$; Kutubdia Island at $0.5 \mathrm{~m}$ depth from mean sea level (MSL); November 2016; IMSCU/I1611.7; one specimen of $59 \mathrm{~mm} \mathrm{SH}$; Inani at $1 \mathrm{~m}$ depth from MSL; November 2016, and IMSCU/ I1611.7; one specimen of $44 \mathrm{~mm} \mathrm{SH}$; St. Martin's Island at 1 $m$ depth from MSL; November 2016; one specimen of $41 \mathrm{~mm}$ SH; St. Martin's Island at $1 \mathrm{~m}$ depth from MSL; January 2017.

\section{Description}

Shell size varied from 30 to $59 \mathrm{~mm} \mathrm{SH}$, and $31-50 \mathrm{~mm}$ in shell width, with an oval to subtriangular shape, depending upon substratum and available room to grow. Left or lower valve attached to substrate by a large attachment area, generally concave (moderately deep), with a large recess under the hinge. Operculiform right or upper valve, flat to slightly convex, forming a "lid," smaller than the left or lower valve, fitting down into the folded margins of the lower valve with angles sculptured on the edge (Fig. 2G, I). Outer surface of upper valve occasionally smooth, but sometimes with distinct radial ribs or having concentrically arranged, imbricating growth plates of a horny-like material. Irregular hyote spines rising vertically from right (or upper) valve surfaces occasionally present on juvenile members of this species (Fig. 2K, L). Inner edge of the upper (or right) valve with small elongated denticles producing corresponding depressions on lower valve. The folds of lower valve provide obvious sharp crenulations (Fig. 2G). Commissural shelf not obvious. Hinge line is straight and short. Ligamental area also short. Umbonal cavity present on left (or lower) valve. Promyal chamber presents on right side of lower valve. Adductor muscle scar is distinct, on the upper (right) valve, and kidney shaped, occupying a quarter of the total shell length, with a white to grayish coloration, whereas the muscle scar on the lower (left) valve is less distinct, being a bit excavated on the hinge side, and greatly displaced toward the posterodorsal side. Interior of valves with a crescent shaped series of small disjunct pallial imprints between the posterior adductor scar and anterodorsal margin. Chomata present encircling the whole interior margin of the shell.

\section{Distribution}

This oyster species was found predominantly in lower intertidal zones and with a wide geographical distribution along the entire southeast coast of Bangladesh, including brackish to marine waters with salinity varying from 5 to $37 \mathrm{ppt}$. This species inhabits a variety of coastal habitats such as sandy, muddy, and rocky shores, mangrove areas and even on coral reefs, though it is found particularly on hard substrates (e.g., jetty pilings, concrete dikes, sluices, water control sluice gates into coastal aquaculture ponds, boulders, and all sorts of other available hard substrates) within the system.

\section{Remarks}

The systematics of the genus Saccostrea has been much muddied in the past. Nevertheless, our phylogenetic analysis confirmed the identification of Saccostrea cucculatta under two different lineages (i.e., lineage B and F) (See Fig. 2G-L). The presence of hyote spines at the intersecting rib points have been found in juvenile $S$. cucculatta specimens sampled from Kutubdia Island. The samples from Inani, Teknaf, and Saint Martin's Islands, however, did not show any spines on the shell surface, likely because they had been eroded from the high-wave energy.

\section{Saccostrea mordax (Gould 1850)}

(Fig. 2M-O)

Ostrea mordax (Sowerby 1871, Saville-Kent 1891)

Ostrea cornucopiae (Saville-Kent 1891)

Ostrea mordax var. cornucopiaeformis (Saville-Kent 1893)

Ostrea (Lopha) cuccullata (Hirase 1930, Takatsuki 1949)

Ostrea forskali var. mordax (Lamy 1929)

Saxostrea amasa (Iredale 1939)

Crassostrea amasa (Thompson et al. 1954, Carreon 1969)

Saxostrea mordax (Habe 1951, Habe \& Kosuge 1967)

Saccostrea mordax (Habe \& Okutani 1975, Habe 1977,

Torigoe 1981, Hayami 2000)

Saccostrea cuccullata (Morris 1985, Li \& Qi 1994, Lamprell \& Healy 1998).

\section{Material Examined}

IMSCU/I1701.13; three specimens of $43-50 \mathrm{~mm} \mathrm{SH}$; St. Martin's Island at 1-2 m depth from MSL; January 2017.

\section{Description}

Shell elongated, with undulations on entire margin of both valves up to the ligamentary region (Fig. 2M, O). Left (lower attached) valve concave. The edge of the left (lower) valve is built up steeply along both the anterior and posterior margins. These margins are thick, with dense layers of squamae running along the margins. Right (upper) valve flat or slightly convex, not opercular (Fig. 2N). Inner edge of the upper (right) valve with denticles along its edges; rounded, relatively large, 
and distributed in a single row. Upper (right) valve producing a corresponding depression in the lower valve, whereas the folds provide extensive marginal crenulations rising from the folds (Fig. 2M). The left (lower) valve attached completely to the substratum with a thin white calcite pad in juvenile stages (sizes 10-20 mm SH). Commissural shelf not distinct; umbonal cavity well-developed, with an extensive anterior projection. Adductor muscle scar oval, grayish to nonpigmented. Muscle impression on right (upper) valve is distinct. The chomata are whitish, and present in a single line around the inner shell margin, rod shaped, prominent dorsally along the anterior and posterior margins, gradually fading toward ventral shell margin. Nonincubatory in nature. The external surfaces of both left and right valves are white to lilac with a dark purple coloration at the shell's margin. White radiating stripes may be present externally on the right valves of some specimens. The interior of the shell is white with a shiny, pearly appearance. The adductor muscle scar is relatively large and positioned along the posterior-ventral half of the pallial area. It is circular to elongate to oval according to the growth form of the shell. It is mostly white or slightly stained with growth bands of purple.

\section{Distribution}

Along the Saint Martin's Island, Saccostrea mordax occurs as individuals within rock pool areas. The coastal environment of this island is oceanic and very exposed to high energy waves (i.e., $0.5-2.75 \mathrm{~m}$ wave heights) and a high salinity of approximately $37 \mathrm{ppt}$.

\section{Remarks}

The species Saccostrea mordax has been identified previously as Saccostrea cuccullata (p. 7, Siddique et al. 2007). This species is often confused with $S$. cuccullata because the two species have similar shell characteristics. Our molecular results have shown that $S$. cuccullata and $S$. mordax are different lineages as has been reported for other regions (Lam \& Morton 2006). This is also a new record of this species not only from the coastal waters of Bangladesh, but also as a new addition to those oysters occurring within the Bay of Bengal region.

\section{Phylogenetic Analysis}

Fragments of the COI gene were successfully sequenced from all 15 oyster sample DNAs from five locations and analyses indicated five lineages of oysters under two subclades in the areas investigated. All sequences obtained in this study have been deposited in the National Center for Biological Information GenBank. GenBank accession numbers of sequences and collection locations for the reference oysters used in this study are provided here (see Table 11). The NJ, MP, and ML trees were constructed with COI sequences obtained from collected oyster samples as well as the GenBank sequences. The model selected for the ML analysis was the TIM3 + I + G model. All trees separated the two genera Crassostrea and Saccostrea. In addition, the COI sequences from analyzed oysters were placed in the same species/lineage clades in the NJ, MP, and ML trees (see Figs. 3 and 4), although some of the more than $100 \mathrm{ML}$ trees with scores of 5,534.443 had two groups of Saccostrea cuccullata lineage B sequences with the Saccostrea mordax clade between them (Fig. 3B). Even the more than 10,000 equally parsimonious MP trees of length 1536 steps maintained the same species/lineage clades (Fig. 3). CbK1, CbK3, CgM1, and $\mathrm{CbS} 1$ from three locations clustered with Crassostrea species, and oysters ScK2, ScK4, ScK5, SkK6, ScI1, ScI2, ScT1, $\mathrm{SkS} 2, \mathrm{SmS} 3$, and $\mathrm{SmS} 4$ from four locations clustered with Saccostrea species, confirming their genus assignment based on shell morphology (see Figs. 3 and 4). Oysters CbK1, CbK3, and $\mathrm{CbS} 1$ clustered with Crassostrea belcheri from India, Myanmar, Thailand, and Malaysia on the COI tree with high support $(\mathrm{MP}=100 \%, \mathrm{ML}=96 \%)($ Fig. 3$)$. The K2P genetic distance between oysters $\mathrm{CbK} 1, \mathrm{CbK} 3$, and $\mathrm{CbS} 1$ and $C$. belcheri ranged from $0 \%$ to $0.7 \%$ (Table 1). Oyster $\mathrm{CgM} 1$ clustered with Crassostrea gryphoides from India and Myanmar on the COI trees (Figs. 3 and 4) and the K2P distances among this clade ranged from $0.3 \%$ to $2.7 \%$ (Table 1 ).

Clade affiliation based on the COI sequences indicated that some of the investigated oysters were affiliated with two different lineages of the Saccostrea genus. Sequences from oysters ScFK2, ScFK4, ScFI1, ScFI2, and ScFT1 clustered with the Saccostrea cuccullata lineage F sequences from China, Malaysia, and Japan with $100 \%$ BS support in MP and $90 \%$ support in ML analyses (Fig. 4). The K2P genetic distance between COI sequences of ScK2, ScFK4, ScFI1, ScFI2, ScFT1, and $S$. cuccullata lineage F ranged from $0.2 \%$ to $1.5 \%$ (Table 1 ), significantly lower than the genetic distances among most other COI sequences from Asian Saccostrea species. Within this clade of $S$. cuccullata lineage F COI sequences also were sequences from oysters identified as Saccostrea malabonensis from Japan and Myanmar. Cytochrome oxidase subunit II sequences for ScBK5, ScBK6, ScBK7, and ScBS2 were clustered with $S$. cuccullata lineage B COI sequences with 100\% MP BS support. Within this clade there was also a COI sequence from an oyster identified as Saccostrea kegaki from Japan. All other S. kegaki COI sequences, however, clustered together in a separate clade with $100 \%$ BS support in MP and $92 \%$ support in ML analyses. The K2P genetic distances among the COI sequences of $\mathrm{ScBK} 5, \mathrm{ScBK} 6, \mathrm{ScBK} 7$, and ScBS2 ranged from $0 \%$ to $1.2 \%$ (Table 1). The genetic distance was also less than $1.2 \%$ between ScBK6 and the Japanese $S$. kegaki COI sequence and sequences from oysters identified as Saccostrea echinata and Saccostrea glomerata from China. Two other $S$. glomerata sequences from Australian oysters in the phylogenetic analyses, however, clustered in a separate clade in all analyses with $100 \%$ BS support in MP and 99\% BS support in ML. The oysters SmAS3 and SmAS4 clustered with a $S$. mordax lineage A COI sequence from China with a K2P genetic distance between them and the $S$. mordax lineage A sequence of $0.5 \%$, significantly lower than the genetic distances among most known species of Saccostrea.

\section{DISCUSSION}

The diversity of oyster species from Bangladesh, and much of the Bay of Bengal is poorly known. Although seven oyster species (Crassostrea ariakensis, Crassostrea gigas, Crassostrea gryphoides, Crassostrea nippona; Crassostrea virginica, and Saccostrea cuccullata) were previously described from Bangladesh coastal waters based on external shell morphological characteristics (Siddique et al. 2007), there has been no genetic confirmation of these species identifications, resulting in some uncertainty with regard to their classifications. We collected oyster specimens from five different oyster habitats located along the southeast coast of Bangladesh, and 
A

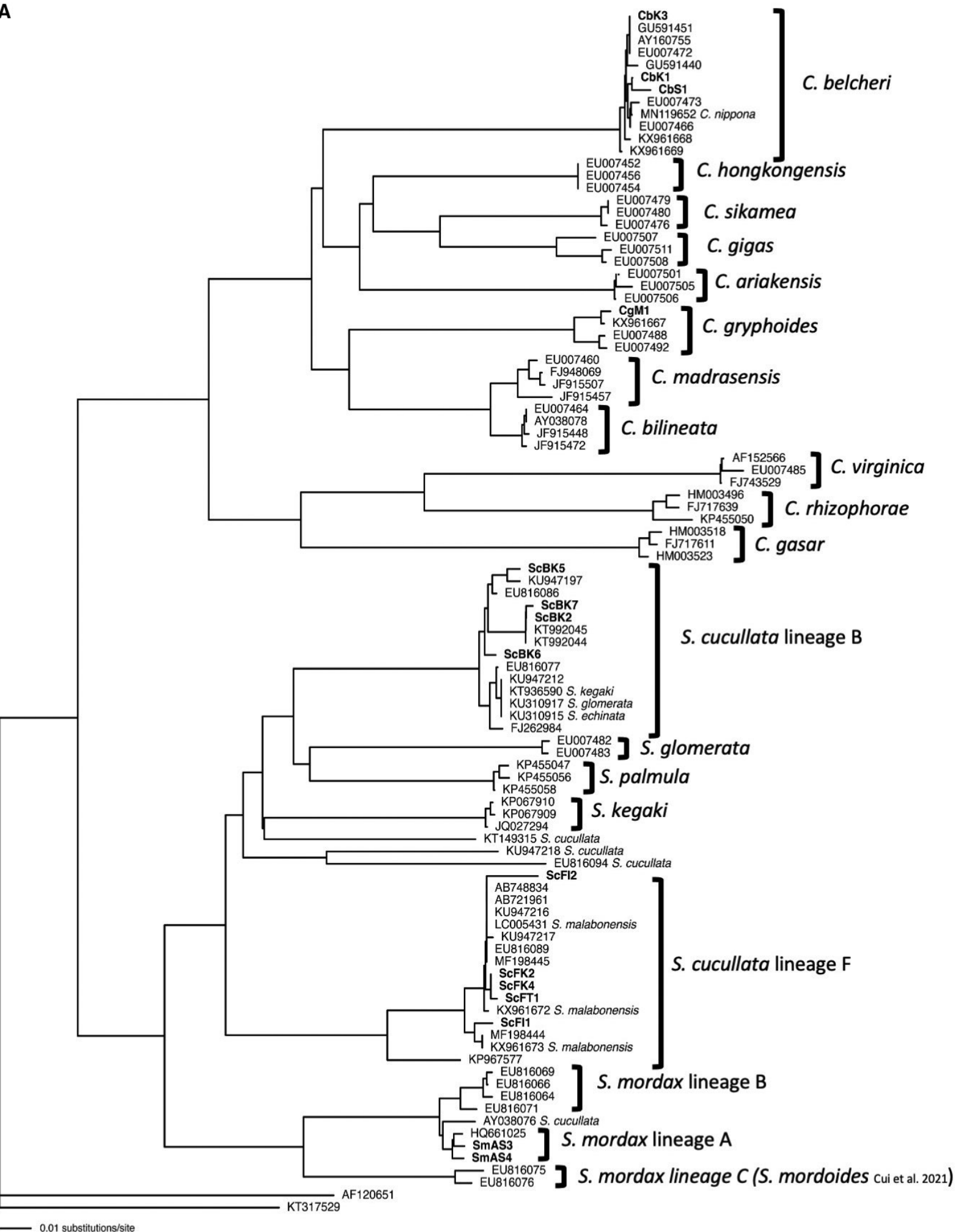

Figure 3. Phylogenetic trees resulting from (A) neighbor joining (NJ) based on Kimura two-parameter (K2P) distances, and (B) maximum likelihood (ML) using the TIM3 + I + G model in analyses of cytochrome oxidase subunit I (COI) gene fragments. 


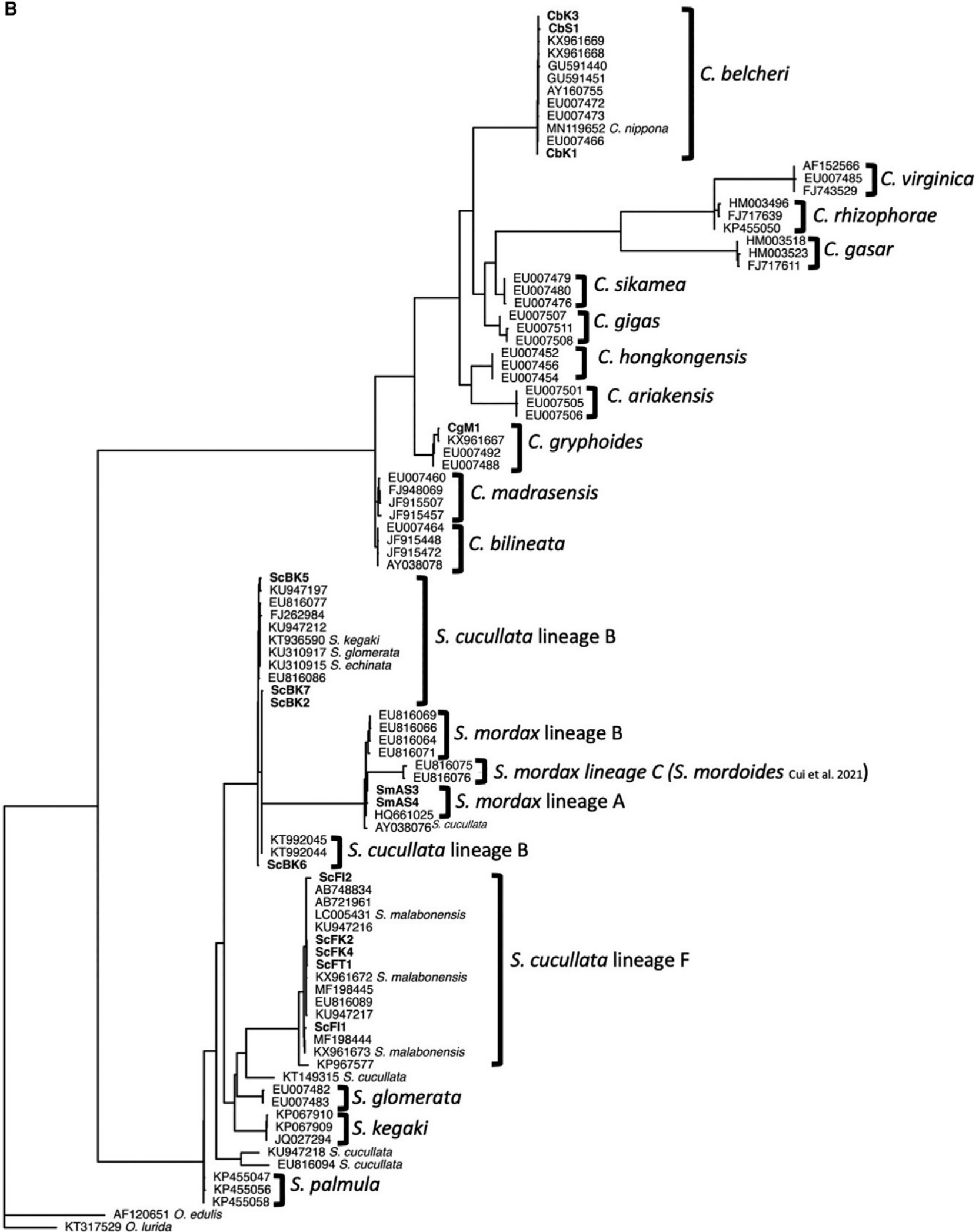

Figure 3. (continued) 


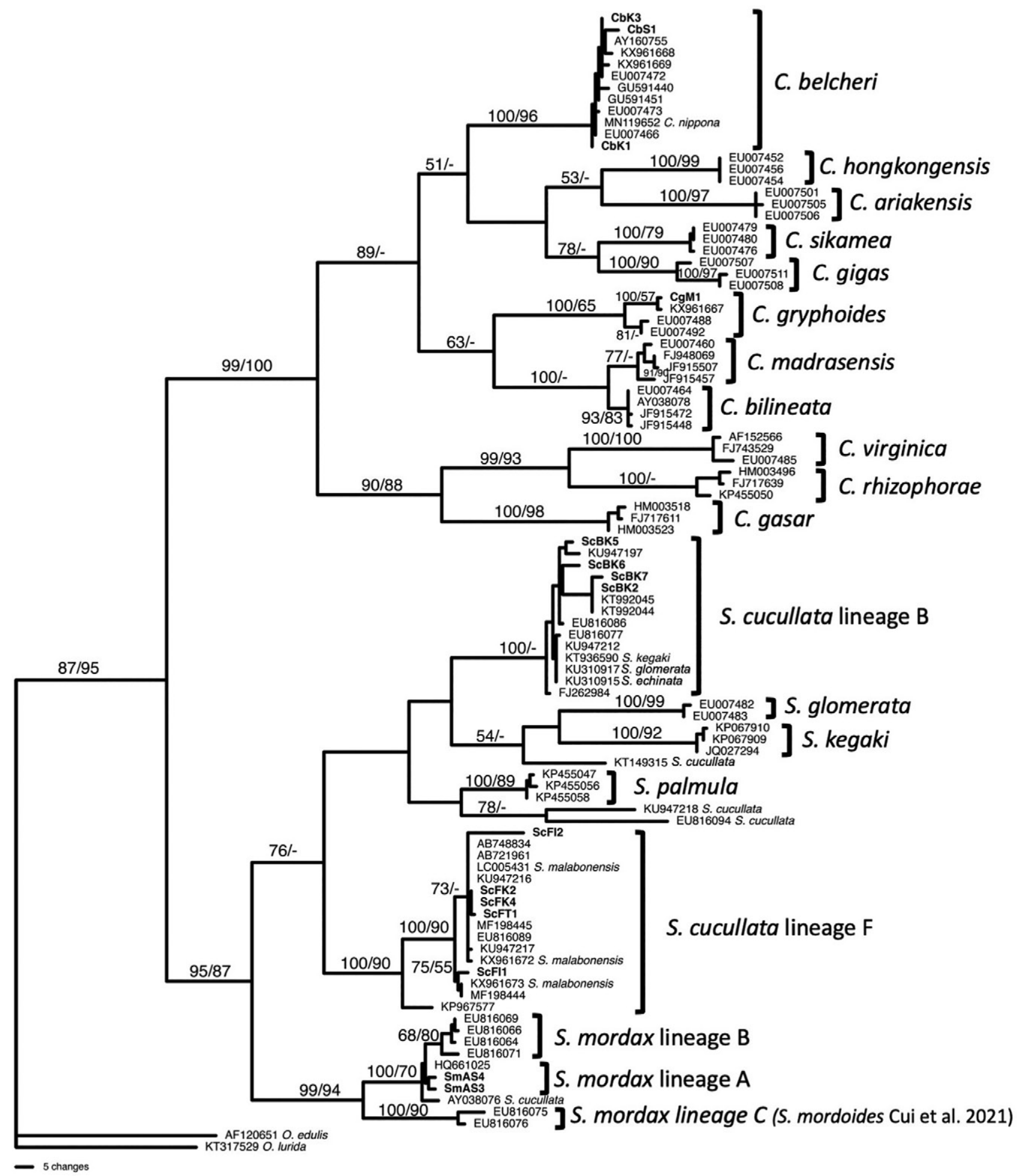

Figure 4. One of more than 10,000 most parsimonious trees of length 1536 generated in maximum parsimony (MP) analysis with MP and maximum likelihood (ML) bootstrap (BS) support values indicated for clades on the branches as indicated (MPBS/MLBS). 
then conducted morphological analysis based on shell characters, and phylogenetic analysis based on the COI mitochondrial gene as a first attempt at a genetic analysis for Bangladesh and larger Bay of Bengal oysters. These morphological and genetic analyses identified five oyster lineages, composed of four species, belonging to two genera Crassostrea and Saccostrea (i.e., Crassostrea belcheri, C. gryphoides, S. cuccullata lineages B, and $\mathbf{F}$ and Saccostrea mordax lineage A). Previously, Li et al. (2017) and Trivedi et al. (2014) added molecular identification of three and nine oyster species from the eastern (Myanmar) and western coasts (India) of the Bay of Bengal, respectively. The common species in those studies were C. belcheri, C. gryphoides, and $S$. cuccullata, which indicates a potentially widespread distribution of these three species along the coast of the Bay of Bengal.

On the contrary, Saccostrea mordax is a new record for the Bay of Bengal region including the coastal waters of Andaman and Nicobar Islands. In a review of the literature published from the Bay of Bengal region to date describing oyster species based on either morphometric (Awati \& Rai 1931, Rao 1987, NACA 1988, Rao \& Dey 2000, Siddique et al. 2007, Wanninayake 2017, Psomadakis et al. 2019), or phylogenetic characters (Trivedi et al. 2014, Amarakoon 2016, Li et al. 2017), $S$. mordax was not identified. Nevertheless, $S$. mordax has been reported previously from various intertidal and subtidal locations in other South Asian regions, including Hong Kong, Taiwan, China, and Japan (Day et al. 2000, Lam \& Morton 2006).

The phylogenetic tree from our molecular analysis of the material collected from Bangladesh, showed monophyletic genus clades within the Ostreidae family, for Crassostrea and Saccostrea. Within the Crassostrea gryphoides clade the COI sequence from the Bangladeshi oyster CgM1 grouped with a C. gryphoides subspecies from Tanintharyi, Myanmar, named Crassostrea gryphoides tanintharyiensis ( $\mathrm{Li}$ et al. 2017). In the same clade, but slightly less similar are the sequences from oysters collected from Dwarka, India (Reece et al. 2008). The genetic distance between the $C O I$ gene of oyster $\mathrm{CgM} 1$ and that of C. gryphoides tanintharyiensis is only $0.3 \%$. Li et al. (2017) argued that the name $C$. gryphoides is for a species that became extinct over 3 million years ago (Harzhauser et al. 2016) and therefore, should not be used for an extant species. They further proposed two subspecies of C. gryphoides, C. gryphoides dwarkaensis, and C. gryphoides tanintharyiensis for the oysters from Tanintharyi, Myanmar, and Dwarka, India, respectively. Thus, using the subspecies designation of Li et al. (2017), the oyster CgM1 from Bangladesh would be C. gryphoides tanintharyiensis.

This study provides the genetic confirmation for the occurrence of Crassostrea belcheri in Bangladesh, which is a new record for that country. The COI sequence of three oysters collected for this study showed clade affiliation with the $C$. belcheri oysters from the Indo-West-Pacific found in India, Myanmar, Thailand, Malaysia, and Hong Kong (Klinbunga et al. 2005, Reece et al. 2008, Suzana et al. 2011, Trivedi et al. 2014, Li et al. 2017).

The genus Saccostrea includes Saccostrea cuccullata, Saccostrea echinata (Quoy \& Gaimard 1835), Saccostrea mordax (Gould 1850), Saccostrea malabonensis, and Saccostrea kegaki (Torigoe \& Inaba 1981) from the Indo-Pacific (Stenzel
1971, Torigoe 1981, Li et al. 2017); Saccostrea glomerata (Gould 1850) from Australia and New Zealand; and Saccostrea palmula (Carpenter 1857) from Mexico to Ecuador. The taxonomy of the Saccostrea species complex has been considered problematic because of the occurrence of significant morphological plasticity among its constituent species (Lam \& Morton 2006).

Molecular analysis for other regions indicates that Saccostrea cuccullata is a superspecies, and thus can be divided into several genetically distinct groups or species that include (1) Saccostrea kegaki; (2) Saccostrea glomerata; (3) Saccostrea echinata; and different morphs of (4) S. cuccullata (Lam \& Morton 2006, Reece et al. 2008). The DNA sequence analysis in this study shows that the collected Bangladeshi oysters ScFK2, ScFK4, ScFI1, ScFI2, and ScFT1 COI sequences are not only within the $S$. cuccullata lineage F sequences, but are also in the same clade as COI sequences from oysters identified as Saccostrea malabonensis from Myanmar and Japan. The name S. malabonensis is a unique name for the problematic $S$. cuccullata usage (Li et al. 2017). Thus, oysters within this clade (i.e., the $S$. cuccullata lineage F clade), including the Bangladeshi oysters (ScFK2, ScFK4, ScFI1, ScFI2, and ScFT1) might be considered to be $S$. malabonensis. Moreover, the COI trees from all three analyses, NJ, MP, and ML, also placed the COI sequence of an oyster identified as $S$. kegaki from Morozaki, Japan, with ScBK2, ScBK5, ScBK6, and ScBK7 in the S. cuccullata lineage B clade. Nevertheless, most $S$. kegaki sequences, in particular, those from Korean and Taiwanese oysters are in another distinct clade, and the COI sequences from our Bangladeshi oysters did not group with those $S$. kegaki sequences in any of the analyses (Figs. 3 and 4).

The well-developed lamella and hyote spines on the external surface of the valves (see Figs. 4 and 5) are considered to be key morphological features for Saccostrea cuccullata and Saccostrea kegaki (Lam \& Morton 2006, Sekino \& Yamashita 2016). Oysters from Kutubdia Island (e.g., ScBK6 and ScBK7) showed hyote spines in juvenile specimens (5-45 $\mathrm{mm} \mathrm{SH}$ ), losing them as they grew. These hyote spines represent a derived generic phenotype (Reece et al. 2008). Taylor (1990) suggested that hyote spines may be an antipredatory device against drilling muricid gastropods that often prey on oysters. Both muricid oyster drills (e.g., genus Thais spp.), as well as stone crabs (Myomenippe hardwickii) are considered mesopredators (Chowdhury et al. 2020), both being abundant at the Kutubdia Island site where juvenile oysters with the hyote spines were sampled. It may be the case that the phenotype of hyote spine growth is a character that is expressed in some $S$. cuccullata populations in the presence of predators (Palmer 1990).

The genetic distance between putative Saccostrea mordax and the other Saccostrea lineages is relatively large (14.1\%$18.2 \%$, Figs. 3 and 4) and can be clearly separated genetically from other Saccostrea lineages. The species S. mordax occurs only on exposed coastal areas, whereas other Saccostrea lineages can occupy a wide range of habitats from estuarine mangroves to less exposed marine shores (Reece et al. 2008). For this study $S$. mordax was found along the exposed coast of Saint Martin's Island, which is the only rocky, offshore island with coral reefs in Bangladesh. Habitats for the other Saccostrea lineages in Bangladesh are geographically quite variable, including sheltered shallow coastal areas and estuaries in the Kutubdia, Moheshkhali, Inani, and Teknaf regions (Fig. 1). 
Results presented here provide important information on the phylogeny of habitat building Ostreid oysters from the northern Bay of Bengal, which is the first attempt of its kind for Bangladeshi oysters, along with comparisons from prior regional analyses. This study documents the natural occurrence of Crassostrea belcheri, and Saccostrea mordax, and confirms two distinct lineages for Saccostrea cuccullata for the first time in Bangladesh and the northern Bay of Bengal waters, and thus extends the geographical distribution of the genera Crassostrea and Saccostrea. The finding of newly recorded oysters from the Bay of Bengal region highlights the need for more oyster sampling, as well as for their molecular classification. This information can be used to help monitor the native localities of oysters being used for both restoration of native beds, as well as aquaculture related to the global movement of oyster species, particularly in the Indo-Pacific region (Ruesink et al. 1995, 2005).

\section{ACKNOWLEDGMENTS}

M. S. N. C acknowledges the support from Virginia Institute of Marine Sciences (VIMS) to visit Dr. Reece, and her lab in Virginia for discussions related to this effort. M. S. N. C. is thankful to Professor Mark W. Luckenbach (VIMS) for providing lodging and discussions while visiting Virginia. VIMS contribution number 4041 .

\section{LITERATURE CITED}

Ahmed, A. T. 2016. Mollusc shell: a descriptive catalogue of mollusc shells in Bangladesh. Bangladesh National Museum, Ministry of Cultural Affairs, Government of the People's Republic Bangladesh.

Ahmed, A. T. \& M. R. Islam. 1978. A preliminary report on the molluscan fauna of the Bay of Bengal. J. Asiat. Soc. Bangladesh. Sci. III:59-82.

Ahmed, M. 1971. Oyster species of west Pakistan. Pak. J. Zool. 3:229-238.

Ahmed, M. 1975. Speciation in living oysters. Adv. Mar. Biol. 13:357-397.

Amarakoon, A. A. D. G. U. 2016. Molecular identification of oyster (Crassostrea sp.) in Sri Lanka from mitochondrial DNA sequence data. World Sci. News 57:116-121.

Arkema, K. K., G. Guannel, Verutes, G, S. A. Wood, A. Guerry, M. Ruckelshaus, P. Kareiva, M. Lacayo \& J. M. Silver. 2013. Coastal habitats shield people and property from sea-level rise and storms. Nat. Clim. Chang. 3:913-918.

Asif, M. 1975. Ecology and reproductive biology of oysters from Karachi Coast. Ph. D. thesis, University of Karachi, Pakistan.

Awati, P. R. \& H. S. Rai. 1931. Ostrea cuccullata (the Bombay oyster). Ind. Zool. Mem. 3:1-107.

Banks, M. A., D. Hedgecock \& C. Waters. 1993. Discrimination between closely related Pacific oyster species (Crassostrea) via mitochondrial DNA sequences coding for large subunit rRNA. Mol. Mar. Biol. Biotechnol. 2:129-136.

Bayne, B. L. 2017. Biology of oyster. Saint Louis, MO: Elsevier Science.

Beck, M. W., R. D. Brumbaugh, L. Airoldi, A. Carranza, L. D. Coen, C. Crawford, O. Defeo, G. J. Edgar, B. Hancock, M. Kay, H. Lenihan, M. W. Luckenbach, C. L. Toropova, G. Zhang \& X. Guo. 2011. Oyster reefs at risk and recommendations for conservation, restoration and management. Bioscience 61:107-116.

Born, I. 1778. Index Rerum Naturalium Musei Caesarei Vindobonensis, pars prima, Testacea. Ex Officina Krausiana, Vindobonae, Austria. 442 pp.

Boudry, P., S. Heurtebise, B. Collet, F. Cornette \& A. Geı'rard. 1998. Differentiation between populations of the Portuguese oyster, Crassostrea angulata (Lamark) and the Pacific oyster, Crassostrea gigas (Thunberg), revealed by mtDNA RFLP analysis. J. Exp. Mar. Biol. Ecol. 226:279-291.
Boudry, P., S. Heurtebise \& S. Laper'gue. 2003. Mitochondrial and nuclear sequence variation of presumed Crassostrea gigas and Crassostrea angulata specimens: a new oyster species in Hong Kong? Aquaculture 228:15-25.

Carpenter, P. P. 1857. Catalogue of the collection of Mazatlan shells, in the British Museum: collected by Frederick Reigen. Department of Zoology, British Museum (Natural History), London. 552 pp.

Carranza, A., O. Defeo \& M. Beck. 2009. Diversity, conservation status and threats to native oysters (Ostreidae) around the Atlantic and Caribbean coasts of South America. Aquat. Conserv. 19:344-353.

Carreon, J. A. 1969. The malacology of Philippine oysters of the genus Crassostrea and a review of their shell characters. Proc. Natl. Shellfish. Assoc. 59:104-114.

Chemnitz, J. H. 1785. Neues systematisches ConchylienCabinet, vol. 8. Nurnberg, Germany: Bauer and Raspe.

Chen, T. P. 1972. Status and problem of coastal aquaculture in Thailand. In: Pillai, T. V. R., editor. Coastal aquaculture in the Indo-Pacific region. London, England: Whitefriars Press. pp. 74-83.

Chowdhury, M. S. N., M. S. Hossain, T. Ysebaert \& A. C. Smaal. 2020. Do oyster breakwater reefs facilitate benthic and fish fauna in a dynamic subtropical environment? Ecol. Eng. 142:105635.

Coan, E. V., P. Valentich-Scott \& F. R. Bernard. 2000. Bivalve seashells of western North America: marine bivalve mollusks from Arctic Alaska to Baja California. NAT HIST Monographs. 2:1-764.

Coen, L. D. \& R. E. Grizzle. 2016. Bivalve Molluscs. In: Kennish, M. J., editor. Encyclopedia of estuaries. Dordrecht, The Netherlands, Heidelberg, Germany, New York, NY, London, England: Springer. pp. 89-109.

Cordes, J. F., J. Xiao \& K. S. Reece. 2008. Discrimination of nine Crassostrea oyster species based upon restriction fragment-length polymorphism analysis of nuclear and mitochondrial DNA markers. J. Shellfish Res. 27:1155-1161.

Cui, Z., L. Hu, C. Li, Z. Zhang, X. Guo \& H. Wang. 2021. Identification of Saccostrea mordax and a new species Saccostrea mordoides sp. nov. (Bivalvia: Ostreidae) from China. J. Shellfish Res. 40:63-75.

Dall, W. H. 1889. A preliminary catalogue of the shell-bearing marine mollusks and brachiopods of the SE coast of the 
U.S. with illustrations of many of the species. Bull. U. S. Natl. Mus. 37:1-232.

Day, A. J., A. J. S. Hawkins \& P. Visootiviseth. 2000. The use of allozymes and shell morphology to distinguish among sympatric species of the rock oyster Saccostrea in Thailand. Aquaculture 187:51-72.

do Amaral, V. S. \& L. R. L. Simone. 2016. Comparative anatomy of five species of Saccostrea Dollfus and Dautzenberg, 1920 (Bilvalvia: Ostreidae) from the Pacific ocean. Nautilus 130:53-71.

Dollfus, G. F. \& P. Dautzenberg. 1920. Conchyliogie du Miocène moyen du bassin de la Loire, pt. 1: Pélécypodes (Suite et fin). Paleontologie 22:379-500.

Dumbauld, B. R., J. L. Ruesink \& S. S. Rumrill. 2009. The ecological role of bivalve shellfish aquaculture in the estuarine environment: a review with application to oyster and clam culture in West Coast (USA) estuaries. Aquaculture 290:196-223.

Durve, V. S. 1967. On the nomenclature of two Indian backwater oysters. J. Mar. Biol. Assoc. India 9:173-178.

Durve, V. S. 1974. Malacological differences between the oysters, Crassostrea gryphoides (Schlotheim) and Crassostrea madrasensis (Preston). Indian J. Fish. 20:624-625.

FAO. 2018. Global aquaculture production. United Nations Fisheries and Aquaculture Department. Available at: http:// www.fao.org/statistics/en/.

Fitzsimons, J., S. Branigan, R. D. Brumbaugh, T. McDonald \& P. S. E. zu Ermgassen, editors. 2019. Restoration guidelines for shellfish reefs. Arlington, VA: The Nature Conservancy. $72 \mathrm{pp}$.

Folmer, O., M. Black, W. Hoeh, R. Lutz \& R. Vrijenhoek. 1994. DNA primers for application of mitochondrial cytochrome c oxidase subunit I from diverse metazoan invertebrates. Mol. Mar. Biol. Biotechnol. 3:294-299.

Galvão, M. S. N., P. M. F. Alves \& A. W. S. Hilsdorp. 2017. First record of the Saccostrea oyster in Bertioga, Sao Paulo, Brazil. Bol. Inst. Pesca 43:638-645.

Galvão, M. S. N., O. M. Pereire \& A. W. S. Hilsdorp. 2013. Molecular identification and distribution of mangrove oysters (Crassostrea) in an estuarine ecosystem in southeast Brazil: implications for aquaculture and fisheries management. Aquacult. Res. 44:1589-1601.

Gmelin, J. F. 1791. Caroli a Linne' Systema naturae per regnatria naturae. Editio 13, Tome 1. Pars 6. Leipzig, Germany: G. E. Beer. pp. 3021-3910.

Gould, A. A. 1850. Shells of the United States exploring expedition. Proc. Boston Soc. Nat. Hist. 3:343-348.

Grabowski, J. H. \& C. H. Peterson. 2007. Restoring oyster reefs to recover ecosystem services. In: Cuddington, K., J. E. Byers, W. G. Wilson \& A. Hastings, editors. Ecosystem engineers: concepts, theory and applications. Burlington, MA: Elsevier/Academic Press. Ch. 15, pp. 281-298.

Guo, X., C. Li, H. Wang \& Z. Xu. 2018. Diversity and evaluation of living oysters. J. Shellfish Res. 37:755-771.

Habe, T. 1951. Genera of Japanese shells. Pelecypoda and Scaphopoda. Kairui-Bunken-Kankokai, Tokyo. 326 pp.

Habe, T. 1977. Taxonomy of Japanese mollusks: Bivalvia and Scaphopoda. Zukan-no-Hokuryukan, Tokyo (in Japanese).

Habe, T. \& S. Kosuge. 1967. Shells of the world in colour, II. The tropical Pacific. Osaka, Japan: Hoikusha. 194 pp.
Habe, T. \& Okutani. 1975. Mollusca II. Tokyo, Japan: Gakken. 294 pp.

Harry, H. W. 1985. Synopsis of supraspecific classification of living oysters (Bivalvia: Gryphaeidae and Ostreidae). Veliger 28:121-158.

Harzhauser, M., A. Djuricic, O. Mandic, T. A. Neubauer, M. Zuschin \& N. Pfeifer. 2016. Age structure, carbonate production and shell loss rate in an early Miocene reef of the giant oyster Crassostrea gryphoides. Biogeosciences 13:1223-1235.

Hasan, A. S. 1960. Oyster fishing resources of Pakistan. Proc. 4th Cong. OIOSA. Kar. (Sec. B). 167 pp.

Hayami, I. 2000. Family Ostreidae. In: Okutani, T., editor. Marine Mollusks in Japan. Tokyo, Japan: Tokai University Press. pp. 924-927.

Hedgecock, D., G. Li, M. A. Banks \& Z. Kain. 1999. Occurrence of the Kumamoto oyster Crassostrea sikamea in the Ariake Sea, Japan. Mar. Biol. 133:65-68.

Hirase, S. 1930. On the classification of Japanese oysters. Jpn. J. Zool. 3:1-65.

Hornell, J. 1918. The edible molluscs of the Madras Presidency. Madras Fish. Bull. 11:10-16.

Hossain, M. S., S. M. Sharifuzzaman, S. R. Chowdhury, M. S. N. Chowdhury, S. Sarker, M. R. Islamd \& A. Talukdar. 2014. Sea shells of Bangladesh: marine gastropod and bivalve molluscs biodiversity. Centre for Coast, Climate and Communities (Tetra-C) and Institute of Marine Sciences and Fisheries, University of Chittagong, Chittagong, Bangladesh.

Hsiao, S. T., S. C. Chuang, K. S. Chen, P. H. Ho, C. L. Wu \& C. Allen. 2016. DNA barcoding reveals that the common cupped oyster in Taiwan is the Portuguese oyster Crassostrea angulata (Ostreoida; Ostreidae), not C. gigas. Sci. Rep. 6:34057.

Iredale, T. 1939. 'Mollusca: part I' British Museum (Natural history). Great Barrier Reef Expedition 5:209-245.

Jones, C. G., J. H. Lawton \& M. Shachak. 1994. Organisms as ecosystem engineers. Oikos 69:373-386.

Jones, C. G., J. H. Lawton \& M. Shachak. 1997. Positive and negative effects of organisms as physical ecosystem engineers. Ecology 78:1946-1957.

Kazmi, M. A. S. 1953. Preliminary investigation on the oyster beds in the Korangi Creek. Agric. Pak. 4:143-150.

Kimura, M. 1980. A simple method for estimating evolutionary rates of base substitutions through comparative studies of nucleotide sequences. J. Mol. Evol. 16:111-120.

Klinbunga, S., P. Ampayup, A. Tassanakajon, P. Jarayabhand \& W. Yoosukh. 2000. Development of species-specific markers of the tropical oyster (Crassostrea belcheri) in Thailand. Mar. Biotechnol. (NY) 2:476-484.

Klinbunga, S., P. Ampayup, A. Tassanakajon, P. Jarayabhand \& W. Yoosukh. 2001. Genetic diversity and molecular markers of cupped oysters (Genera Crassostrea, Saccostrea, and Striostrea) in Thailand revealed by randomly amplified polymorphic DNA analysis. Mar. Biotechnol. (NY) 3:133-144.

Klinbunga, S., N. Khamnamtong, N. Puanglarp, P. Jarayabhand, W. Yoosukh \& P. Menasveta. 2005. Molecular taxonomy of cupped oysters (Crassostrea, Saccostrea, and Striostrea) in Thailand based on COI, 16S, and 18S rDNA polymorphism. Mar. Biotechnol. (NY) 7:306-317.

Klinbunga, S., N. Khamnamtong, A. Tassanakajon, N. Puanglarp, P. Jarayabhand \& W. Yoosukh. 2003. Molecular genetic 
identification tools for the three commercially cultured oysters (Crassostrea belcheri, Crassostrea iredalei, and Saccostrea cuccullata) in Thailand. Mar. Biotechnol. (NY) 5:27-36.

Kong, C. P. \& L. A. Luh. 1977. Notes on the efficiency of various materials tested as oyster spat collectors in Cowie Bay, Sabah. Malays. J. Sustain. Agric. 50:462-479.

Krause, G., B. H. Buck \& A. Breckwoldt. 2019. Socioeconomic aspects of marine bivalve production. In: Smaal, A., J. Ferreira, J. Grant, J. Petersen \& Ø. Strand, editors. Goods and services of marine bivalves. Cham, Switzerland: Springer.

Lam, K. \& B. Morton. 2003. Mitochondrial DNA and morphological identification of a new species of Crassostrea (Bivalvia: Ostreidae) cultured for centuries in the Pearl River Delta, Hong Kong, China. Aquac. 228:1-13.

Lam, K. \& B. Morton. 2004. The oysters of Hong Kong (Bivalvia: Ostreidae and Gryphaeidae). Raffles Bull. Zool. 52:11-28.

Lam, K. \& B. Morton. 2006. Morphological and mitochondrial-DNA analysis of the Indo-West Pacific rock oysters (Ostreidae: Saccostrea species). J. Molluscan Stud. 72:235-245.

Lamarck, J. B. P. de M. 1819. Histoire naturelle des animaux sans vertebres. Suite des conchiferes. Paris, France: Chez L'Auteur. 258 pp.

Lamprell, K. \& J. Healy. 1998. Bivalves of Australia, vol. 2. Leiden, The Netherlands: Backhuys Publishers. 288 pp.

Lamy, E. 1929. Revision des Ostrea vivants du Muse'um National d'Histoire Naturelle de Paris. J. de. Conch. 7:1-46, 71-108, 133-168, 233-275.

Leray, M. \& N. Knowlton. 2015. DNA barcoding and metabarcoding of standardized samples reveal patterns of marine benthic diversity. Proc. Natl. Acad. Sci. USA 112:2076-2081.

Li, C., M. Haws, H. Wang \& X. Guo. 2017. Taxonomic classification of three oyster (Ostreidae) species from Myanmar. $J$. Shellfish Res. 36:365-371.

Li, X. \& Z. Qi. 1994. Studies on the comparative anatomy, systematic classification and evolution of Chinese oysters. Stud. Mar. Sin. 35:143-173.

Littlewood, D. T. J. 1994. Molecular phylogenetics of cupped oysters based on partial 28S rRNA gene sequences. Mol. Phylogenet. Evol. 3:221-229.

Liu, J., Q. Li, L. Kong, H. Yu \& X. Zheng. 2011. Identifying the true oysters (Bivalvia: Ostreidae) with mitochondrial phylogeny and distance-based DNA barcoding. Mol. Ecol. Resour. 11:820-830.

Lohan, K. M. P., K. M. Hill-Spanik, M. E. Torchin, E. E. Strong, R. C. Fleischer \& G. M. Ruiz. 2015. Molecular phylogenetics reveals first record and invasion. Mar. Biol. 162:957-968.

Milbury, C. A., D. W. Meritt, R. I. E. Newell \& P. M. Gaffney. 2004. Mitochondrial DNA markers allow monitoring of oyster stock enhancement in the Chesapeake Bay. Mar. Biol. 145:351-359.

Morris, S. 1985. Preliminary guide to the oysters of Hong Kong. Asian Mar. Biol. 2:119-138.

Nagabhushanam, R. \& U. H. Mane. 1991. Oysters in India. In: Menzel, W., editor. Estuarine and marine bivalve mollusk culture. Boca Raton, FL: CRC Press. pp. 202-209.

Network of Aquaculture Centres in Asia. 1988. Status of oyster culture in selected Asian countries. Bangkok, Thailand: NACA-SF/WP/88/2.
O’Foighil, D., P. M. Gaffney \& T. J. Hilbish. 1995. Differences in mitochondrial 16s ribosomal gene-sequences allow discrimination among American [Crassostrea virginica (Gmelin)] and Asian [C. gigas (Thunberg) C. ariakensis Wakiya] oyster species. J. Exp. Mar. Biol. Ecol. 192:211-220.

O'Foighil, D., P. M. Gaffney, A. E. Wilbur \& T. J. Hilbish. 1998. Mitochondrial cytochrome oxidase I gene sequences support an Asian origin for the Portuguese oyster Crassostrea angulata. Mar. Biol. 131:497-503.

Orton, J. H. 1928. The dominant species of Ostrea. Nature 121:320-321.

Palmer, A. R. 1990. Effect of crab effluent and scent of damaged conspecifics on feeding, growth, and shell morphology of the Atlantic dogwhelk Nucella lapillus (L.). Hydrobiologia 193:155-182.

Patel, S. K. \& K. L. Jetani. 1991a. Study of oysters from Gulf of Kutch. Fish. Chimes 11:56-57.

Patel, S. K. \& K. L. Jetani. 1991b. Survey of edible oysters from Saurashtra coast, current. Bioscience 8:79-82.

Psomadakis, P. N., H. Thein, B. C. Russell \& M. T. Tun. 2019. Field identification guide to the living marine resources of Myanmar. FAO Species Identification Guide for Fishery Purposes. Rome, Italy: FAO and MOALI.

Quoy, J. R. C. \& J. P. Gaimard. 1835. Voyage de découvertes de l'Astrolabe exècuté par ordre du Roi pendant les années 1826-1827-1828-1829, sous le commandment de M.J. Dumont D'Urville Zoologie. Tome 3 (part I). Tastu, Paris.

Rafinesque, C. S. 1815. Analyse de la nature ou tableau de l'universet des corps organisés. Le nature es mon guide, et Linnéus mon maître. Palermo, Italy: Privately published. 224 pp.

Rai, H. S. 1933. The shell fisheries of the Bombay Presidency. Report on the Bombay Natural History Society's Survey. $J$. Bombay Nat. Hist. Soc. 35:826-847.

Ranjah, A. R. 1960. Edible molluses of Pakistan. Proc. 4th Cong. OIOSA. Kar. (Sec. B) pp. 167-171.

Ranson, G. 1960. Les Prodissoconques (Coquiles larvaires) des Ostre'ides vivant. Bull. Inst. Oceanogr. 1183:1-41.

Rao, K. S. 1974. Edible bivalves mussels and oysters. In: The Commercial moIluscs of India. Bull. Cent. Mar. Fish. Res. Inst. 25:4-39.

Rao, K. S. 1987. Taxonomy of Indian oysters. Bull. Cent. Mar. Fish. Res. Inst. 38:1-6.

Rao, N. V. S. \& A. Dey. 2000. Catalogue of marine molluscs of Andaman and Nicobar Islands. Rec. Zool. Surv. 187:1-323.

Reece, K. S., J. F. Cordes, J. B. Stubbs, K. L. Hudson \& E. A. Francis. 2008. Molecular phylogenies help resolve taxonomic confusion with Asian Crassostrea oyster species. Mar. Biol. 153:709-721.

Reece, K. S., G. P. Scott, C. Dang \& C. F. Dungan. 2017. A novel monoclonal Perkinsus chesapeaki in vitro isolate from an Australian cockle, Anadara trapezia. J. Invertebr. Pathol. 148:86-93.

Romashko, S. 1992. The shell book: Florida, Gulf, and Caribbean. Lakeville, MN: Windward Publishing.

Ruesink, J. L., H. S. Lenihan, A. C. Trimble, K. W. Heiman, F. Micheli, J. E. Byers \& M. C. Kay. 2005. Introduction of non-native oysters: ecosystem effects and restoration implications. Annu. Rev. Ecol. Evol. Syst. 36:643-689.

Ruesink, J. L., I. M. Parker, M. J. Groom \& P. M. Kareiva. 1995. Reducing the risks of nonindigenous species introductions: guilty until proven innocent. Bioscience 45:465-477. 
Sacco, F. 1897. Pelecypoda (Osteridae, Anomiidae Dimyidae). In: Bellardi, L. \& F. Sacco, editors. I. Molluschi dei terreni Terziarii del Piemonte e della Liguria. Torino, Italy: Carlo Clausen. 66 pp.

Salvi, D., A. Macaliand \& P. Mariottini. 2014. Molecular phylogenetics and systematics of the bivalve family Ostreidae based on rRNA sequence-structure models and multilocus species tree. PLoS One 9:e108696.

Saville-Kent, W. 1891. Oysters and oysters fisheries of Queensland. Brisbane, Australia: Queensland Govt. Rept. $17 \mathrm{pp}$.

Saville-Kent, W. 1893. Great Barrier Reef of Australia; Its products and potentialities. London, England: W. H. Allen and Co. Ltd. 387 pp.

Sekino, M. \& H. Yamashita. 2013. Mitochondrial DNA barcoding for Okinawan oysters: a cryptic population of the Portuguese oyster Crassostrea angulata in Japanese waters. Fish. Sci. 79:61-76.

Sekino, M. \& H. Yamashita. 2016. Mitochondrial and nuclear DNA analyses of Saccostrea oysters in Japan highlight the confused taxonomy of the genus. J. Molluscan Stud. 82:492-506.

Siddique, K. U., M. A. Islam, S. M. H. Kabir, M. Ahmad, A. T. A. Ahmed, A. K. A. Rahman, E. U. Haque, Z. U. Ahmed, Z. N. T. Begum, M. A. Hassan, M. Khondker \& M. M. Rahman, editors. 2007. Encyclopedia of flora and fauna of Bangladesh, vol. 17 Molluscs. Dhaka, Bangladesh: Asiatic Society of Bangladesh. 415 pp.

Sowerby, G. B. 1871. Conchologia Iconica, vol. 18. London, England: Ostrea. L. Reeve and Co.

Stenzel, H. B. 1971. Oysters. In: Moore, R. C., editor. Treatise on invertebrate paleontology, Part N III (III), Mollusca 6, Bivalvia. Boulder, CO: Geological Society of America and the University of Kansas. pp. N 953-N 1224.

Suzana, M., A. M. Lutfi, A. A. Hadi, M. N. D. Evakie \& M. N. S. Azizah. 2011. Genetic variation in Malaysian oysters: taxonomic ambiguities and evidence of biological invasion. Biol. Invasions 13:1893-1900.

Swofford, D. L. 2002. PAUP Phylogenetic analysis using parsimony (and other methods). vs 4.0b10. Sunderland, UK: Sinauer Associates.

Tack, J. F., E. Berghe \& P. H. Polk. 1992. Ecomorphology of Crassostrea cuccullata (Born, 1778) (Ostreidae) in a mangrove creek (Gazi, Kenya). Hydrobiologia 247:109-117.

Takatsuki, S. 1949. Oyster. Gihoudo Publ. Co., Tokyo. 262 pp. [In Japanese].

Taylor, J. D. 1990. Field observations of prey selection by the muricid gastropods Thais clavigera and Morula musiva feeding upon the intertidal oyster Saccostrea cuccullata. In: Morton, B., editor. The marine flora and fauna of Hong Kong and southern China II. Proceedings of the Second International Workshop: The Marine Flora and Fauna of Hong Kong and Southern China, Hong Kong. Hong Kong: Hong Kong University Press. pp. 837-855.
Thompson, J. D., D. G. Higgins \& T. J. Gibson. 1994. Improving the sensitivity of progressive multiple sequence alignment through sequence weighting, positions-specific gap penalties and weight matrix choice. Nucleic Acids Res. 22:4673-4680.

Torigoe, K. 1981. Oyster in Japan. J. Sci. Hiroshima Univ., Ser. B, Div. 1 (Zol.). 29:291-419.

Torigoe, K. \& A. Inaba. 1981. On the scientific name of Japanese spiny oyster "Kegaki". Venus 40:126-134.

Trivedi, S., A. A. Aloufi, A. Ansari \& S. K. Ghosh. 2014. Molecular phylogeny of oysters belonging to the genus Crassostrea through DNA barcoding. J. Entomol. Zool 3:21-26.

Tucker Abbott, R. \& P. A. Morris. 1995. Shells of the Atlantic and Gulf Coasts and the West Indies, $4^{\text {th }}$ edition. New York, NY: Houghton Mifflin Company.

Varela, E. S., C. R. Beasley, H. Schineider, I. Sampaio, N. S. Marques-Silva \& C. H. Tagliaro. 2007. Molecular phylogeny of mangrove oysters (Crassostrea) from Brazil. J. Molluscan Stud. 73:229-234.

Vredenburg, E. 1904. Recent and sub-recent marine bed in Calcutta. Rec. Geol. Surv. India 31:174-176.

von Schlotheim, E. F. 1820. Die Petrefactendunde auf ihrem jetzigen Standpunkte durch die Bescheribung seiner Sammlung versteinerter und fossiler Uberreste des Theirund Pflanzenreichs der Vorwelt erlautert. Gotha, Germany: Beckersche Buchhandlung.

Wang, H., X. Guo, G. Zhang \& F. Zhang. 2004. Classification of jinjiang oysters Crassostrea rivularis (Gould, 1861) from China, based on morphology and phylogenetic analysis. Aquaculture 242:137-155.

Wang, H., L. Qian, X. Liu, G. Zhang \& X. Guo. 2010. Classification of a common cupped oyster from southern China. J. Shellfish Res. 29:857-866.

Wanninayake, W. M. T. B. 2017. Current status of bivalve farming in Sri Lanka. 6th Global Summit on Aquaculture and Fisheries 2017, Osaka, Japan.

Wilk, J. \& R. Bieler. 2009. Ecophenotypic variation in the flat tree oyster, Isognomon alatus (Bivalvia: Isognomonidae), across a tidal microhabitat gradient. Mar. Biol. Res. 5:155-163.

Xia, J., X. Wu, S. Xiao \& Z. Yu. 2014. Mitochondrial DNA and morphological identification of a new cupped oyster species Crassostrea dianbaiensis (Bivalvia: Ostreidae) in the South China Sea. Aquat. Living Resour. 27:41-48.

Zhang, Q., S. K. Allen, Jr. \& K. S. Reece. 2005. Genetic variation in wild and hatchery stocks of Suminoe oyster (Crassostrea ariakensis) assessed by PCR-RFLP and microsatellite markers. Mar. Biotechnol. (NY) 7:1-13.

Zu Ermgassen, P. S. E., M. D. Spalding, P. Banks, B. Blake, L. Coen, B. Dumbauld, S. Geiger, J. H. Grabowski, R. Grizzle, M. Luckenbach, K. McGraw, B. Rodney, J. Ruesink, S. Powers \& R. Brumbaugh. 2012. Historical ecology with real numbers: past and present extent and biomass of an imperilled estuarine ecosystem. Proc. Royal Soc. B. 279:3393-3400. 